\title{
The Determinants of Cash Holdings around Different Regions of the World
}

\begin{abstract}
Ummar Aftab ${ }^{1}$, Attiya Yasmin Javid ${ }^{2}$, Waseem Akhter ${ }^{3}$
Abstract

This paper analyzes cash holding determinants around different regions of the world including Asia Pacific, Europe, Africa, North America, Middle East and South America. The sample consists of 5,957 companies from 47 countries grouped into six regions for the period from 2007 to 2016. Panel Generalized Method of Moments is applied to account for endogeneity in the independent variables. The study is conducted in two phases: in the first stage, model is run for all the companies where results of the analysis show that size, financial strength, investments and cash flows are positively and significantly related to cash holdings for the companies in the sample while leverage, dividend, intangibles, market to book ratio, profitability and net working capital have significant negative effect on cash holdings. In the second phase, model is run separately for each region. The results show deviations across the regions which indicate differences of institutional frameworks in different countries present in different regions of the world. The study is of immense importance for the international managers and academic researchers in analyzing cash holding determinants in different regions having varying institutional and governance settings.
\end{abstract}

Keywords: Cash holding determinants, Cross-Region analysis, GMM

\section{Introduction}

In perfect capital markets, cash holding decision is irrelevant because firms can easily generate funds from the financial markets to finance their investments at insignificant cost. Hence, shareholders' wealth does not change with the change in liquid assets of the firms. However, recent studies demonstrate that firms maintain cash holdings by investing in liquid assets. For example, In UK, Al-Najjar and Belghitar (2011) identify that cash is $9 \%$ of the total assets of the companies. Gao, Harford, and Li (2013) analyze that in USA, public firms hold cash or cash equivalents as

1 PhD Scholar, Capital University of Science and Technology, Islamabad.

Email:ummaraftab71@hotmail.com

2 HoD, Department of Economics, PIDE Islamabad. Email: attiyajavid@pide.org.pk

3 Capital University of Science and Technology, Islamabad

\begin{tabular}{lll}
\multicolumn{2}{l}{ ARTICLE HISTORY } \\
4 Mar, 18 & Submission Received & 11 Apr, 18 First Review \\
\hline 20 Apr, 18 & Revised Version Received & 5 Jun, 18 Second Review \\
\hline 11 Jun, 18 & Revised Version Received & 22 Jun, 18 Accepted
\end{tabular}


18.8\% of their total assets. Kato, Li and Skinner (2017) find that cash constitutes $10 \%$ of the total assets for Japanese companies. Guizani (2017) identifies that cash holdings are $14 \%$ of total assets in Saudi companies. This shows that cash represents a considerable asset for firms.

The literature has been discussing motives to hold cash reserves for the last many years. Apart from the traditional motives of cash holdings including transaction, precautionary and speculative motives, many theories including Free Cash Flow (FCF) by Jensen and Meckling (1976) and pecking-order theory by Myers and Majluf (1984) have been tested in the literature (Acharya, Viral, Almeida, \& Campello, 2007; Faleye, 2004; Weidemann, 2016) However, such studies normally focus on specific situations of cash hoarding and develop conflicting results about impact of the most common cash determinants across these situations. Resultantly, it is difficult to draw a general statement regarding determinants of cash holdings from the existing research. This study is an attempt to derive the answer of the question; what determine level of cash holdings?

Major area of research on determinants of cash holdings covers firms from the United States. Some exceptions are Dittmar, Mahrt-Smith, \& Servaes, (2003), Pinkowitz, Stulz, and Williamson (2006) as well Kalcheva and Lins (2007). Although said studies are conducted in international settings, focus of the researchers is to analyze how corporate governance influences cash holdings of the companies. Dittmar et al. (2003) show that it is common tendency that companies of the countries where shareholders' protection is weak hold more cash as compared to the companies which operate in the countries where shareholders' protection is strong. Pinkowitz et al. (2006) identify that value of the firm is weakly correlated with cash holdings in the countries where investors' protection is poor as compared to the countries where investors' rights are strongly protected. Kalcheva and Lins (2007) investigate that value of the cash stockpiled is discounted by outside investors when agency problems exist in the firms. In other words, value of the cash is decreased in the companies where controlling managers hold more cash.

There are other examples of cross country studies which show effect of institutional factors on cash holdings i.e. political uncertainty (Julio \& Yook, 2012), investor protection (Huang \& Kisgen, 2013; Jia \& Iskandar-Datta, 2014), country characteristics (Pinkowitz, Stulz, \&Wiilamson, 2015) or cultural effect (Chen, Dou, Rhee,Truong, \& Veeraraghavan, 2015). A comprehensive study on company specific determinants of cash holdings across different regions is not made previously.

Apart from the above, Al Najjar (2013) analyzes cash holding determinants in developing countries including China, Russia, Brazil and India. Floyed, Lee and Skinner 
(2015) investigate cash hoarding behavior in Japan. Wang (2015) investigated factors affecting cash holding decision in public and private companies of China. Guizani (2017) investigated cash holding determinants for Saudi companies. Although, cash holding determinants in different countries have been examined by these studies, there is still a need to generalize the impact of determinates of cash holdings in a wider setting and this study is an attempt to address this issue.

For the sake of this study, ten determinants of cash holdings, found from literature, are used for making cross region analysis for the said important financial decision. The cash holding determinants used in the study are: Size, dividend, leverage, market to book ratio, Z-score, investment, intangibles, cash flows, profitability and net working capital. Thus, a broader study is conducted in an international context.

This study attempts to investigate the cash holding determinants in different regions of the world including Asia Pacific, Africa, Middle East, Europe, North America and South America. This enables to understand behavior of cash holdings in different regions with varying institutional frameworks. The latest period i.e. 2007 to 2016 are used to analyze effect of cash holding determinants with 5,947 companies from 47 countries. Thus, this paper sheds light on cash hoarding decision in a wider range. This paper is among the first to focus on different regions of the world, thus providing in-depth knowledge to the scholars and practitioners. Also, cross-region analysis enables the readers to examine application of different theories of cash holdings in different regions of the world having varying effects of cash holding determinants on cash reserves.

This study shows that size, dividend, leverage, growth, market to book ratio, risk, Z-score, profitability, net working capital, investments and cash flows are important cash holding determinants. A panel data series across different regions has been examined and it is found that cash holding decision is influenced by regional effects.

In the first part of analysis this study finds cash holdings for all the regions to decline when leverage, dividends, MBR, net working capital, intangibles and profitability increase. The corporate cash reserves increase with increasing total assets, investment activities, Z-score and cash flows.

In the second part of this study, determinants of cash holdings across different regions are observed. In almost all the regions, Z-score and cash flows have positive effect on cash holdings. Leverage, dividend payments and net working capital are negatively associated with cash holdings in most of the regions. Other determinants show mixed results across different regions.

Remaining part of the paper is planned as follows: Section 2 states theory and 
empirical base of cash holding determinants; in Section 3,conceptual framework, hypotheses, empirical specification, data, sample and variables are discussed; Section 4 explains the results; Section 5 concludes the study.

\section{Literature Review}

There are many studies which focus on cash holdings. Some include Ozkan and Ozkan (2004) as well as Al-Najjar and Belghitar (2011) using UK data; Ferreira and Vilela (2004) within EMU countries; Teruel and Solano (2008) working on Spanish SMEs data; Opler, Pinkowitz, Stulz, and Williamson (1999), Dittmar and Smith (2007) and Foley, Hartzell, Titman, and Twite (2007) in US setting. These studies are conducted on developed countries. There are some other studies which use worldwide data (Al- Najjar, 2013; Dittmar et al., 2003; Guney \& Ozkan 2003; Pinkowitz, Stulz \& Williamson, 2015; Ramirez \& Tadesse, 2009; Weidemann, 2016). Apart from determinants of cash holdings, there are some studies which investigate relationship of firm value with cash holdings. Examples include Sola, Teruel, and Solano (2013); Tong (2011); Pinkowitz, Stulz, and Williamson (2006) and Guney and Ozkan (2003).

In UK, cash holding determinants are analyzed by Ozkan and Ozkan (2004).They find negative relationship of cash flows, liquidity, leverage, bank debt, dividend and size with cash holdings and positive association of cash flows, MBR, size and volatility with cash reserves. Also, Najjar and Belghita (2011) also use data of 400 non-financial firms of UK for the period from 1991 to 2008 and identify that dividend, leverage, size, profitability and net working capital negatively influence cash reserves of the firms, whereas, MBR and net working capital are positively associated with cash holdings.

For EMU countries, cash holding determinants are analyzed by Ferreira and Vilela (2004).They find that dividend, leverage and net working capital have negative relationship with cash holdings and MBR, cash flows and size are positively related with cash holdings. In their study, negative relationship of shareholder rights, creditor right, rule of law, ownership concentration with cash holdings support agency view of cash. Teruel and Solano (2008) explain the level of cash holdings in a sample of 860 small and medium-sized firms from Spain during the period 1996-2001. They find that liquidity, bank debt, size, debt maturity, interest rate and GDP are negatively associated with cash holdings and cash flows, growth, financial distress and leverage are positively associated with cash reserves.

Opler et al. (1999) examine the determinants and implications of holdings of cash and marketable securities by analyzing publically traded U.S. firms during the period from 1971-1994. They find that size, net working capital and leverage are negatively associated with cash holdings and MBR, cash flows and capital expenditure 
are positively related with cash reserves.

Dittmar and Smith (2007) find that the value of a Dollar of cash is substantially less if a firm has poor corporate governance. They also identify that a well governed firm has its excess resources better "fenced in," and that firms with poor corporate governance dissipate excess cash reserves more quickly on less profitable investments than those with good governance. They also find that firms with higher growth, riskier activities and small size have more cash holdings, whereas, firms with greater access to capital markets, with higher credit ratings and with large size and more net working capital have lesser cash.

Foley et al. (2007) find that US multinational firms with higher tax on repatriation income hold higher level cash. Further, firms which are less financially constrained and those that are more technology intensive show higher sensitivity of cash holdings to repatriation tax burdens.

Al- Najjar (2013) analyzes the effect of capital structure and dividend policy on cash holdings in Brazil, Russia, India, and China and compare results with a control sample from the US and the UK. He identifies that dividend payment, liquidity and leverage have negative relationship with cash holdings, whereas, profitability and size are positively associated with cash reserves.

Dittmar et al. (2003) study cash holding determinants for a sample of 45 countries around the world. They find that strong shareholder rights have negative effect on cash holdings. They also find that shareholders of the firms with poor shareholder rights are unable to force managers to disgorge cash reserves of the firms. They also find that size and networking capital are negatively related to cash holdings, whereas, market to book ratio, cash flows and intangibles have positive relationship with the cash reserves.

Guney, Ozkan, and Ozkan (2003) investigate corporate cash holding behavior in Japan, France, Germany, and the UK using data for 3,989 companies over the period 1983-2000. They find that higher shareholder right is associated with lower cash holdings and higher creditor right is positively related with cash holdings. They also find that ownership concentration is negatively related with level of cash.

Pinkowitz, Stulz, and Williamson (2015) analyze differences in determination of cash holdings between USA firms and their foreign counterparts. They do not find significant differences in firm specific determinants of cash holdings between US and similar foreign companies. They also find that country factors do not explain cash holdings in US as well as foreign firms. 
Ramirez and Tadesse (2009) examine the relationship between uncertainty avoidance, multi-nationality and firm cash holdings. They find that firms in high uncertainty avoidance index have more cash holdings. They also find that multi-nationality moderates relationship between uncertainty avoidance and cash holdings. They find that multinational firms hold more cash as compared to domestic firms. For firm specific variables, they find that size, leverage, cash flows and cash flows have negative effect on cash holdings and $\mathrm{R} \& \mathrm{D}$ has positive effect on cash reserves. Shareholder rights, control of corruption, stock market capitalization are negatively related with cash holdings and rule of law and credit market capitalization are positively associated with cash reserves.

Weidemann (2016) finds that size, investments, leverage, cash flow and dividend are negatively related with cash holdings and market-to-book ratio, $R \& D$ expenditures, financial distress and corporate governance quality have positive effect on cash holdings. The author identifies that geographic region and firm level asymmetric information influence determinants of cash holdings.

Sola et al. (2013) analyze the effect of cash holding on firm value for a sample of US industrial firms during 2001-2007. They find concave relationship between level of cash and firm value. They also identify that liquidity, leverage, bank debt, intangibles and size are negatively related with cash holdings and cash flows have positive effect on cash reserves.

Tong (2009) studies how firm's diversification affects the value of corporate cash holdings. He finds that value of cash is lower in diversified firms as compared to single segment firms. They also find that value of cash for diversification is lower for both constrained and unconstrained firms. They identify that diversification lowers value of the firm through agency problems.

Pinkowitz, Stulz, and Williamson (2006) identify that relationship between value of the firm and cash holdings is weaker in the countries with poor investor protection as compared to other countries. They also find that relationship between firm value and dividend is weaker in the countries with strong investor protection.

From the above, it is revealed that not only firm specific determinants of cash holdings have been analyzed in the literature; effect of formal and informal institutions on cash holdings has also been studied by some researchers. However, cross region study on determinants of cash holdings is not made previously and this study is an effort to bridge this gap. Also, differences of theoretical impact on cash holdings are analyzed in this study which is a rare attribute of the above mentioned studies. 


\section{Methodology and Data}

Based on theoretical and empirical review, conceptual framework is framed in sub-section 3.1 and hypotheses are formulated in sub-section 3.2. In sub-section 3.3 empirical specification is presented and data, sample and variables are discussed in sub-section 3.4 .

\subsection{Conceptual framework}

Here we provide the theoretical ground of cash holdings. In line with the previous literature we discuss the main theories of cash holdings (Opler et al., 1999; Ozkan \& Ozkan, 2004). Then, we hypothesize effect of different determinants of cash holdings on cash reserves. In this section, we present trade off theory, pecking order theory and agency theory of cash holdings. The reason to discuss different theories is to show that different determinants of cash holdings exert their effect on cash reserves differently under these theories and it is essential to show these variations in the light of previous literature.

\subsubsection{Trade-off theory}

According to this theory, value of the firm is maximum when marginal benefits of holding cash equate marginal costs of cash reserves. Cash holdings result in lower chance of financial distress, lower transaction cost and more opportunities to implement investment projects which may otherwise not be done due to financial constraints (Guizani, 2017). Opportunity cost is the main cost of cash holdings which is the difference between earning from the cash holdings and interest payment on the amount borrowed when needed (Dittmar et al., 2003).

Transaction cost motives and precautionary motives are related to this theory. As described in classic models in finance, when converting a non-cash financial asset into cash is associated with transaction, the demand for cash arises (Miller and Orr, 1966). Accordingly, benefit of economies of scale is associated with large firms so they have lesser cash reserves. These economies of scales are evidenced in the literature. (Al-Najjar \& Belghitar, 2011; Ozkan \& Ozkan, 2004). It is argued that when opportunity costs and fund raising costs are higher the firms hold more cash (Dittmar et al., 2003; Miller \& Orr, 1966).

Further, cash reserves are also needed when capital markets are costly to access. This is another motive to hold cash. According to this motive, firms which have better investment opportunities hold more cash when financial distress is high and cash flows are volatile. The precautionary demand for cash is formulated by Almeida, Campello, and Weisbach (2004) who examine that firms which face financial constraints hold 
more cash whereas firm which are financially strong do not hold excess cash. Acharya, Almeida, and Campello (2007) analyze that when operating income and investment opportunities are poorly correlated, the firms prefer to accumulate cash instead of reducing debt. As per Harford, Mansi, and Maxwell (2008) and Subramaniam, Tang, Yue, and Zhou (2011), financial distress increases level of cash.

It is argued by Ferreira and Vilela (2004) that in case of expected losses, cash holdings help to reduce financial distress. Such firms hoard cash for financing their projects if it is costly to obtain funds from capital market. According to Booth, Aivazian, Kunt, and Maksimovic (2001) and Al-Najjar (2011), emerging markets are more suffered from market imperfections and bankruptcy related costs whereas developed markets do not face such situations and so cash holding decision in the such markets can be better explained by trade off theory.

In empirical studies, different proxies for cash holding determinants are used to test this theory. Firm size, risk, liquidity, leverage and dividend policy are used as cash holding determinants by Ozkan and Ozkan (2004) as well as Al-Najjar and Belghitar (2011). Similarly, growth, size, liquidity and leverage are used by Ferreira and Vilela (2004) to test this theory. Al-Najjar (2013) investigate cash holding determinates including leverage, profitability, liquidity, dividend payments and firm size for BRIC countries.

\subsubsection{The pecking order theory}

This theory advocates absence of optimal cash level. According to this theory, financial hierarchy is followed by firm to reduce cost of information asymmetry (Myers, 1984; Myers \& Majluf, 1984). Firstly, internal sources are used by the firm to finance its investments and then external sources of finance are utilized after internal sources are exhausted.

According to Myers (1984), the firms prefer debt over equity financing as less information cost is associated with debt as compared to equity. The hierarchal pattern of financing determines different financing and investment decisions and cash can be seen as an outcome (Dittmar et al., 2003). They identify that firms with excess cash flows distribute dividend to shareholders; opt for debt and thus stockpile cash.

\subsubsection{The agency theory}

Jensen (1986) assumes that when the firm is confronted with weak investment prospects, the entrenched managers would not increase payment of dividend to the shareholders rather they would prefer to retain cash with them for their discretional uses. The discretionary cash in the hands of managers is knows as excess cash holdings. 
Dittmar et al. (2003) find that firms hold more cash when agency problems are severe. Further, it is investigated by Pinkowitz, Stulz, and Williamson (2006) and Dittmar and Smith (2007) that in case there are more agency problems between insiders and outsiders, value of cash is decreased. It is identified by Dittmar and Smith (2007) and Harford, Mansi, and Maxwell (2008) that although it is more likely that entrenched manager would hoard excess cash, they spend cash quickly.

To recap, in finance literature, no theory can be preferred over the other which can best explain cash holding behavior in the firms and also there are no set of factors which can determine appropriate cash holding determinants. The objective of this study is to identify cash holding determinants for the world as a whole and for samples of different regions of the world.

\subsection{Hypotheses development}

A firm's financial decisions have no impact on value of the firm in perfect market (Stiglitz, 1974). So, it may be assumed that cash holding decisions do not influence value of the firm (Opler et al., 1999). Nevertheless, markets are not free from imperfections, whether developed or developing. So, it is argued that theoretical foundations which are relevant to developed markets are also applicable to developing markets (Al- Najjar, 2013). Based on the previous literature, following cash holding determinants are identified to analyze across different regions of the world.

\subsubsection{Firm size}

Firm size is a commonly used determinant in empirical cash holding research. The determinant is in general estimated by a firm's total assets or their logarithm. Overall, the corporate cash ratio decreases with increasing firm size as Opler et al. (1999), Lins, Servaes, and Tufano (2010) as well Qiu and Wan (2015) report, amongst others. This is consistent with trade off theory of cash holdings. The trade-off model states that large firms obtain edge of economies of scale over small firms so they do not require holding large amount of cash reserves.

However, there are some deviations which indicate that firm size and cash holdings are positively related with each other. Examples include Ozkan and Ozkan (2004) and Liu, Mauer, and Zhang (2015). According to the shareholder power hypothesis, shareholders allow greater cash holdings to the management when their interests are sufficiently secured as it might be the case in large firms that are subject to increased external discipline and decreasing information asymmetries when it grows in size.

Pecking order theory and free cash flow hypothesis also predict positive relationship between firm size and shareholdings. Pecking order theory argues that large firms 
are generally successful and so they have cash out of retained earnings to finance their projects. The free cash flow hypothesis posits that discretionary power of the managers is increased due to dispersion of ownership in large firms so managers of such firms can easily hoard more cash.

Based on the above, it may be argued that firm size is significantly related with cash holdings, though direction of their relationship cannot be estimated with certainty. Thus we hypothesize the following:

H1. Firm size has significant positive/negative effect on cash holdings.

\subsubsection{Leverage}

Another alternative to financing via cash holdings is switching to debt financing. Empirical results support negative relationship between leverage and cash holdings. As Acharya et al. (2008) and Chen et al. (2014) report that cash declines when leverage rises. Additionally, as per pecking order theory, which supports financial hierarchy, argues that leverage is considered as second best alternative of financing after the cash reserves and when available cash is declined leverage is enhanced to finance investment projects. Moreover, as per free cash flow hypothesis, managers of the firms are disciplined by higher leverage and so cash level will be declined. The predictions of trade off theory regarading relationship between leverage and cash holdings are two-fold. On the one hand, as per said theory there should be more cash in the firms due to high risk of bankruptcy, whereas, on the other hand, high leverage mans good relationship of managers of the firms with creditors resulting into lower cost of additional financing,, so lesser need to hoard cash for transaction or precautionary purposes.

Further, the free cash flow theory argues that high leverage ratios would discipline managers and thus less cash would be held. The trade-off model is still ambiguous about its prediction. The ambiguity of the trade-off model is due to the fact that on the one hand highly levered firms should hold more cash because of the increased risk of bankruptcy while on the other hand high leverage ratios indicate good relationships with creditors, representing lower costs of additional financing. Hence, on the basis of pecking order theory, free cash flow hypothesis, trade off theory and previous empirical findings our next hypothesis is:

H2. Leverage and cash holdings are negatively associated with each other.

\subsubsection{Dividend}

Payouts to shareholders constitute the exact opposite of holding cash. Accordingly, majority of the research, such as Khieu and Pyles (2012) and Julio and Yook 
(2012), find that dividend payments are negatively related with corporate cash level. However, there are several observations of a positive relationship between the said variables (Chen, Schipper, Xu, and Xue, 2012; Hill, Fuller, Kelly, and Washam, 2014). Dividend has signaling power which aligns interest of the shareholders and managers and thus shareholders allow the management to stockpile the cash as proposed by the shareholder power hypothesis. The general sign of the cash level and dividend remains ambiguous. On the basis of shareholder power hypothesis and previous empirical findings, it is hypothesized that:

H3. Dividend is significantly and positively/ negatively related with cash holdings.

\subsubsection{Financial distress}

A central determinant under analysis in cash holding research is financial distress which is the probability of insolvency that constrains liquidity of a firm. The determinant of liquidity constraint comprises many proxies such as the volatility of cash flows, credit ratings and Altman's Z-score. Two general trends are observed: First, financial distress increases the cash holdings (Opler et al., 1999; Harford et al.,2008; Subramaniam et al.,2011). Second, according to Lins et al. (2010) and Khieu and Pyles (2012), the influence of the Altman Z-score on the corporate cash level cannot be determined unambiguously. This indicates a nonlinear influence of financial distress on the level of cash. Firms that face an increased but not yet severe danger of insolvency tend to hoard more cash to avoid huge external cost of financing. Firms closed to insolvency are unable to hoard incremental cash and exhaust their existing cash stock because they do not have another option of financing. It remains interesting to derive a general effect of financial distress on cash holdings across. So, our next hypothesis is:

H4. Financial distress is significantly and positively/ negatively related with cash holdings.

\subsubsection{Growth opportunities}

For measurement of growth opportunities, market-to-book ratio and R\&D expenditures are used. Both proxies are commonly found to be positively related with the cash level (Chen et al.,2015; Foley et al.,2007; Iskandar-Datta \& Jia, 2014). Therefore, cash appears to be hoarded to finance corporate growth. This finding follows all major theories because high-growth firms usually face high information asymmetries and are aim to avoid underinvestment. Deviations from the prior observation are found by Khieu and Pyles (2012) and Bigelli and Vidal (2012) who point out growth opportunities do not increase cash holdings in mature and private companies. It is unclear which relationship is more common in the finance literature (Weidman, 2016). 
Furthermore, it is questionable if both proxies equally measure growth opportunities or if they have different meanings. In view of the above, it may be hypothesized that:

H5: Growth opportunities have significant positive/ negative effect on cash holdings

\subsubsection{Investment activities}

Investment activities comprise capital expenditures as well as a firm's acquisition expenditures. The prior are a frequent control variable, while the latter are analyzed specifically by some studies. The cash level is mostly observed to decline when investment activity increases. Dittmar et al. (2003) and Hoberg, Phillips, and Prabhala. (2014) report this result for capital expenditures as well as Bates et al. (2009) and Oler and Picconi (2014) for acquisition expenditures. However, Opler et al. (1999) and Huang et al. (2013) find a positive coefficient for capital expenditures, shedding doubt on direction of the association. Harford (1999), Mikkelson and Partch (2003) and Harford et al. (2008) find an increased investment activity in firms with high cash holdings when applying investment models, still the direction of the investment activities' influence is not clearly determined. We argue that one of the important determinants of cash holdings is capital expenditure, although sign of the direction between cash holdings and investments nay not be predicted precisely. Hence, next hypothesis is:

H6. Investments are significantly associated with cash holdings.

\subsubsection{Cash flows}

Kalcheva and Lins (2007) and D'Mello, Krishnaswami, and Larkin (2008) correspond to the majority of research by reporting that cash flows have positive effect on cash holdings. This follows financing hierarchy of the pecking order theory but can also be explained in the spirit of the FCF hypothesis by increased discretionary potential induced by increased cash flows. Dittmar and Duchin (2010) and Chen et al. (2012) object to prior results and find a negative relationship. However, on the basis of FCF and pecking order theory, it is hypothesized that: mar

H7. Leverage and cash holdings are positively related with each other.

\subsubsection{Profitability}

According to pecking order theory, cash is the outcome of investment and financing decisions (Dittmar et al., 2003). Hence, the firms with more profitability have more ability to pay dividend to their shareholders, meet debt obligation and accumulate cash. Ferreira and Vilela (2004) and Najjar and Clark (2016) also find the 
same results in their studies. The firms which are less profitable may not be able to stockpile cash and they have to rely on debt for financing their projects. Such firms may not be willing to issue equity as the same is costly and reduces value of the shares (Dittmar et al.,2003; Ferreira \&Vilela, 2004; Al Najjar \& Belghitar, 2011). Hence, cash holdings of the firm are increased with increase in profitability. On the basis of empirical findings and pecking order theory, it may be hypothesized that:

H8. Profitability and cash holdings are positively related with each other.

\subsubsection{Net working capital}

An alternative to hoarding cash, without relying on external financing, is the maintenance of liquidity substitutes. These can be converted into cash easily, as long as the transaction costs are not severe. Such liquidity substitutes are commonly measured by the net working capital. In general, cash holdings are found to decrease with an increase in net working capital as stated by Almeida, Campello, and Weisbach (2004), Subramaniam et al. (2011) and Liu et al. (2014). This corresponds to the trade-off theory because liquidity substitutes are able to avoid the costs of stockpiling cash, unless the liquidation of these substitutes is associated to high transaction costs, while preserving its benefits, i.e. financial flexibility. Hence, our next hypothesis is:

H9: Net working capital has significant positive/ negative effect on cash holdings

\subsection{Em pirical specification}

To test the hypotheses, we follow Al Najjar (2013) empirical specification given below:

$\mathrm{CASH}_{i t}=\beta_{0}+\beta_{1} \operatorname{SIZE}_{i t}+\beta_{2} L E V_{i t}+\beta_{3} D I V_{i t}+\beta_{4} Z_{i t}+\beta_{5} I N V S T_{i t}+\beta_{6} M B_{i t}+\beta_{7} I A_{i t}$ $+\beta_{8} C F_{i t}+\beta_{9} R O A_{i t}+\beta_{10} N W C_{i t}+\varepsilon_{i t}$

where CASH is the cash ratio measured by cash and cash equivalents to total assets ratio; Size is measured as natural log of total assets; LEV is the leverage ratio, measured by total debt to total assets; DIV is the dividend payout ratio measured by total dividends to total assets; Z is Z-score, proxy for financial distress; INVST is the capital expenditure to total assets; $\mathrm{MB}$ is market to book ratio; IA is the intangible assets to total assets; CF is operational cash flows to total assets; ROA is net income total assets; NWC is net working capital to total assets; $\square$ is the error term. The calculations for all variables are placed at Table 1 .

The Panel Generalized Method of Movement is applied and lags of explanatory variables are used as instruments. The model is suitable for catering endogeneity problem present in the data. In GMM estimation, not all variables from regression are correlated with error term. As per Roodman (2009), lagged values of the variables 
Table 1: Description of Variables

\begin{tabular}{|c|c|c|}
\hline Symbols & Variables & Description \\
\hline CASH & Cash holdings & Cash and cash equivalents/Total assets \\
\hline SIZE & Firm Size & Natural Log of Total Assets \\
\hline LEV & Leverage & Total debts/ Total assets \\
\hline DIV & Dividend & Cash dividend / Total assets \\
\hline Z & Financial Risk/ Financial strength & ALTMAN Z SCORE \\
\hline INVST & Capital Expenditure/ Investments & Capital expenditure/Total assets \\
\hline MB & Market to Book ratio & Market capitalization + Total liabilities/ Total \\
assets
\end{tabular}

Note: This table presents description of dependent variables i.e. cash holdings and independent variables i.e. size, leverage, dividend, financial risk, capital expenditure, market to book ratio, intangibles, cash flows, profitability and net working capital.

may be taken as instruments. In the present literature, different techniques including OLS, Fixed effect model, random effect models etc. are used to estimate panel data. However, using such techniques to analyze effect of cash holding determinants on cash reserves has drawbacks including omitted variable bias.

Pooled OLS do not consider individual heterogeneity by limiting individual effect; by stating common slope coefficients and intercept for all cross sections. As per Baltagi (2008), fixed effect model reduces the variances and common slop along with country specific intercept but it yields biases due to loss of degree of freedom. The fixed effect model produces biased results when regressors are correlated with error term and are endogenous (Kinoshita and Campos 2008). Arellano (2003) assumes that by assuming common intercept, random effect models solve the problem of degree of freedom, thus they are less unstable, however, random effect models are suffered from problem of "time invariance".

\subsection{Sample and data}

The data is collected for different firms over different time periods, it is known as panel data or longitudinal data. This is due to the reason that it is composed of 
a time series dimension as well as cross-sectional dimension. The cross section data means that observations are being made at a single point of time across many firms or units. The big advantage of panel data over time series or cross section data is that it routinely enhances number of observations which increases degree of freedom and hence more explanatory variables may be employed in the model (Verbeek, 2008). Hence, data becomes more informative and also collinearity between variables is reduced. Nevertheless, panel datasets are often characterized by missing observations because e.g. firms merge or go bankrupt. This is the reason that our initial sample of 25,000 firms over 50 countries reduced to 5,947 firms from 47 countries.

Our sample is composed of six main regions of the world. These regions include Asia Pacific, Europe, Africa, Middle East, North America and South America. The study of cash determinants across different regions enables us to generalize the effect of different factors on cash holdings. This also sheds light on the issue whether cash holding determinants which are significant for one region are also relevant for other region or otherwise.

We use World Scope database and Thomson Financial database to create the sample of 5,947 companies from 47 countries of the world. The data availability is the selection criteria for firms in World Scope and Thomson Financial across the period 2007-2016.

World Scope database and Thomson Financial database contain information about public and private firms. However, we include only public companies in our study because such firms have higher availability of data and also financial data is more consistent in such firms. For a firm to include into study sample, it is necessary to have available accounts for the period from 2007 to 2016. Further, financial firms with SIC codes from 6000 to 6999 and utility firms with SIC codes from 4900 to 4999 are not included in the sample as such firms are subject to more regulations. The said sample requirements follow studies of Opler et al. (1999) and Ferreira and Vilela (2004)

Further, these countries are grouped into six regions of the world to make a comprehensive study worldwide. The detail is placed at Table 2 . The table shows that there are 3 countries in Africa region with 1000 observation. In Asia Pacific region, 15 countries are present with 33,580 observations. Asia Pacific region is the most enriched region in our sample with respect to number of observations. Although, Europe has maximum number of countries in our sample i.e. 20, total number of observations is 13,040 which is lesser than that of Asia Pacific. Similarly, in Middle East, North America and South America, there are 3, 2 and 4 countries respectively with 700, 10140 and 1,010 number of observations respectively. Among all countries 


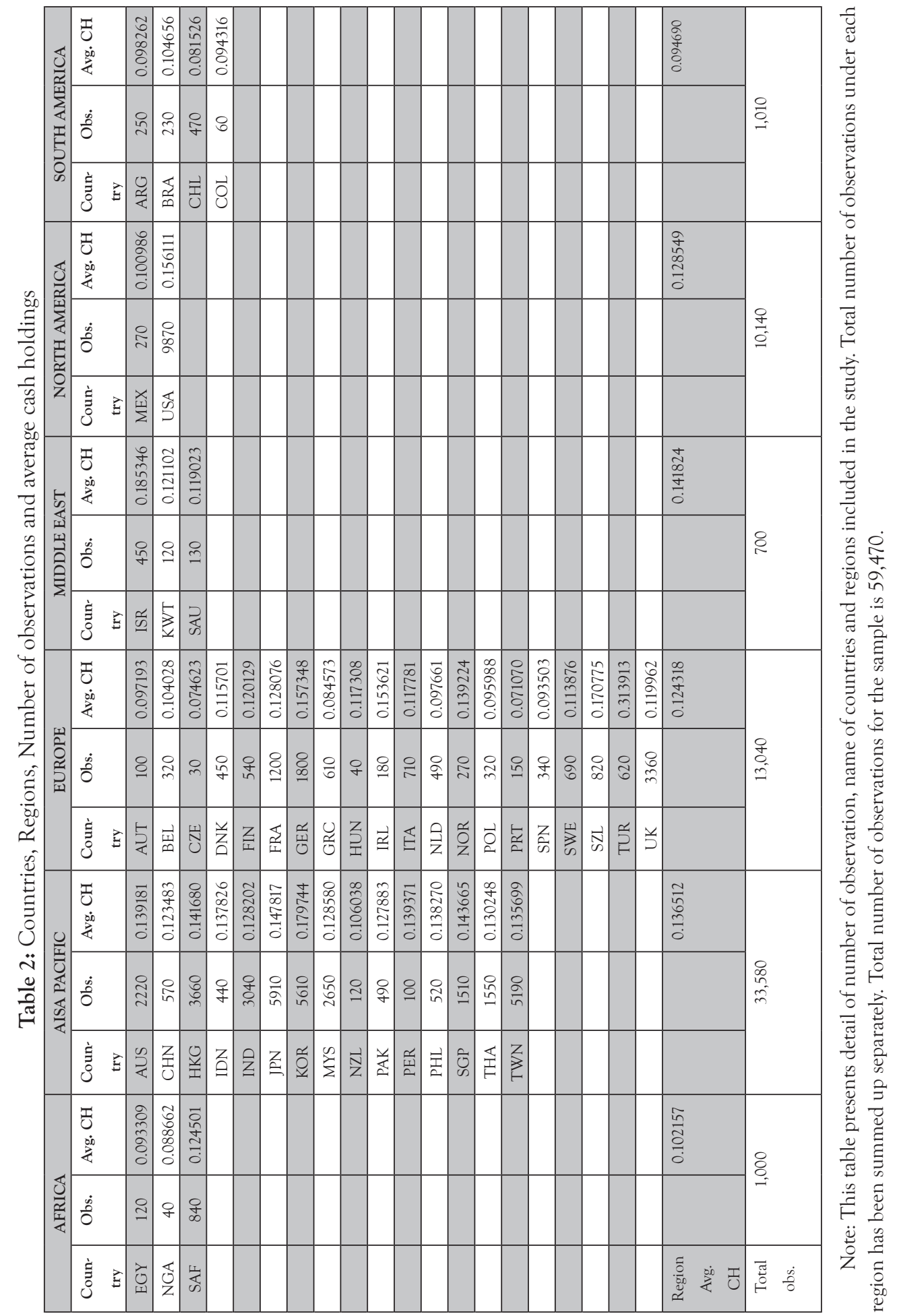


of the six regions, USA has the highest number of observation i.e. 9,870 which is followed by Japan, Malaysia and Thailand with 5,910, 5,610 and 5,190 number of observations respectively.

The table also shows average cash holdings of each country along with average cash per region. The table shows that highest average cash holdings is of Middle East which is $14.18 \%$. This is followed by Asia Pacific and North America with average cash holdings of $13.65 \% \&$ and $12.85 \%$ respectively. Europe has average cash holdings of 12.43 . Africa and South America have average cash holdings of $10.21 \%$ and $9.46 \%$ respectively.

\section{Empirical Results}

The analysis begins with summary statistics and then panel data regression is performed on the whole sample and region wise.

\subsection{Summary statistics}

Table 3 presents combined descriptive statistics for all 5,947 companies from six regions. It shows cash holdings have mean value of $14.80 \%$. This is comparable to 13.68\% which Pinkowitz, Stulz, and Williamson (2015) calculated for 40 countries for the year 2011. However, median value of cash holdings in our world sample is $10.70 \%$ which is lower than mean value of the cash holdings. Similarly, mean, median,

Table 3: Descriptive Statistics

\begin{tabular}{|c|c|c|c|c|c|}
\hline Variables & Mean & Median & Maximum & Minimum & Std. Dev. \\
\hline CASH & 0.148 & 0.107 & 0.674 & 0.000 & 0.134 \\
\hline SIZE & 6.109 & 5.897 & 11.015 & 0.668 & 1.936 \\
\hline LEV & 0.227 & 0.208 & 0.816 & 0.000 & 0.177 \\
\hline DIV & 0.018 & 0.008 & 0.201 & 0.000 & 0.026 \\
\hline Z & 3.314 & 2.372 & 19.486 & -0.861 & 3.327 \\
\hline INVST & 0.044 & 0.031 & 0.207 & 0.000 & 0.043 \\
\hline MBR & 1.532 & 1.137 & 7.871 & 0.284 & 1.254 \\
\hline IA & 0.170 & 0.027 & 1.971 & 0.000 & 0.326 \\
\hline CF & 0.066 & 0.064 & 0.510 & -0.425 & 0.101 \\
\hline ROA & 0.025 & 0.036 & 0.349 & -0.715 & 0.103 \\
\hline NWC & 0.027 & 0.023 & 0.439 & -0.392 & 0.163 \\
\hline
\end{tabular}

Note: This table reports descriptive statistics i.e. mean median, maximum, minimum and standard deviation in respect of cash holdings, total assets, leverage, dividend, z-score, investments, market to book ratio, intangibles, cash flows, profitability and net working capital. 
maximum, minimum and standard deviation for independent variables are placed at Table 3. The table shows that maximum value of cash holdings is $67.40 \%$ and minimum value is $0 \%$ for the said variable. Total assets for the world sample have mean vale of 6.109 and median value of 5.897 with maximum and minimum values of 11.015 and 0.668 respectively. Leverage, Dividends, Z-score, Investments, market to book ratio, Intangibles, cash flows, return on assets and net working capital have mean values of $0.227,0.018,3.314,0.044,1.532,0.170,0.066,00.025$ and 0.027 respectively with median values of $0.208,0.008,2.372,0.031,1.137,0.027,0.064$, 0.036 and 0.023 respectively. Similarly, maximum and minimum values for all the said variables are placed at Table 3 along with standard deviations.

The results of correlation matrix shows that financial strength, capital expenditure and market to book value are positively correlated with cash holdings, whereas, size, leverage, dividend, intangibles, profitability and net working capital are negatively associated with cash holdings. Table 4 presents correlation matrix of cash holdings and explanatory variables. The table revels that correlation between cash and size, leverage, dividend, Z-score, investments, MBR, intangibles, cash flows, profitability and net working capital are $-0.01,-0.22,-0.1,0.36,0.08,0.27,-0.04,-0.07,-0.06$ and0.09 respectively. The correlations among independent variables show that no two variables are so strongly correlated that could create multi-collinearity problem in the regression. The highest correlation is 0.64 between MBR and Z-score which is followed by size \& dividend and dividend \& cash flows with correlation values of -0.53 and 0.52 respectively. All other correlation values are below than 0.50 which indicates that possibility of mult ollinearity is not expected at all. Generally correlation coefficient of 0.70 between two variable indicates presence of multi-collinearity which is not present in our data.

\subsection{Results of panel data regression analysis}

For better presentation and analysis, we divide the results into two sub-sections: Sub-section 4.2.1 discusses regression results for the world data, whereas, in sub-section 4.2.2 region wise results are presented. . Hausman test supports the fixed effect model. To deal with the endogeneity problem generalized method of moments (GMM) is used as estimation technique. The lags of explanatory variables are used as instruments and Sargan J test supports the validity of the instruments. The Sargan test is based on the assumption that model parameters are identified via a priori restrictions on the coefficients, and tests the validity of over-identifying restrictions.

\subsubsection{Regression results of world data}

In this part, equation (3.1) is estimated for the whole sample which shows financial 


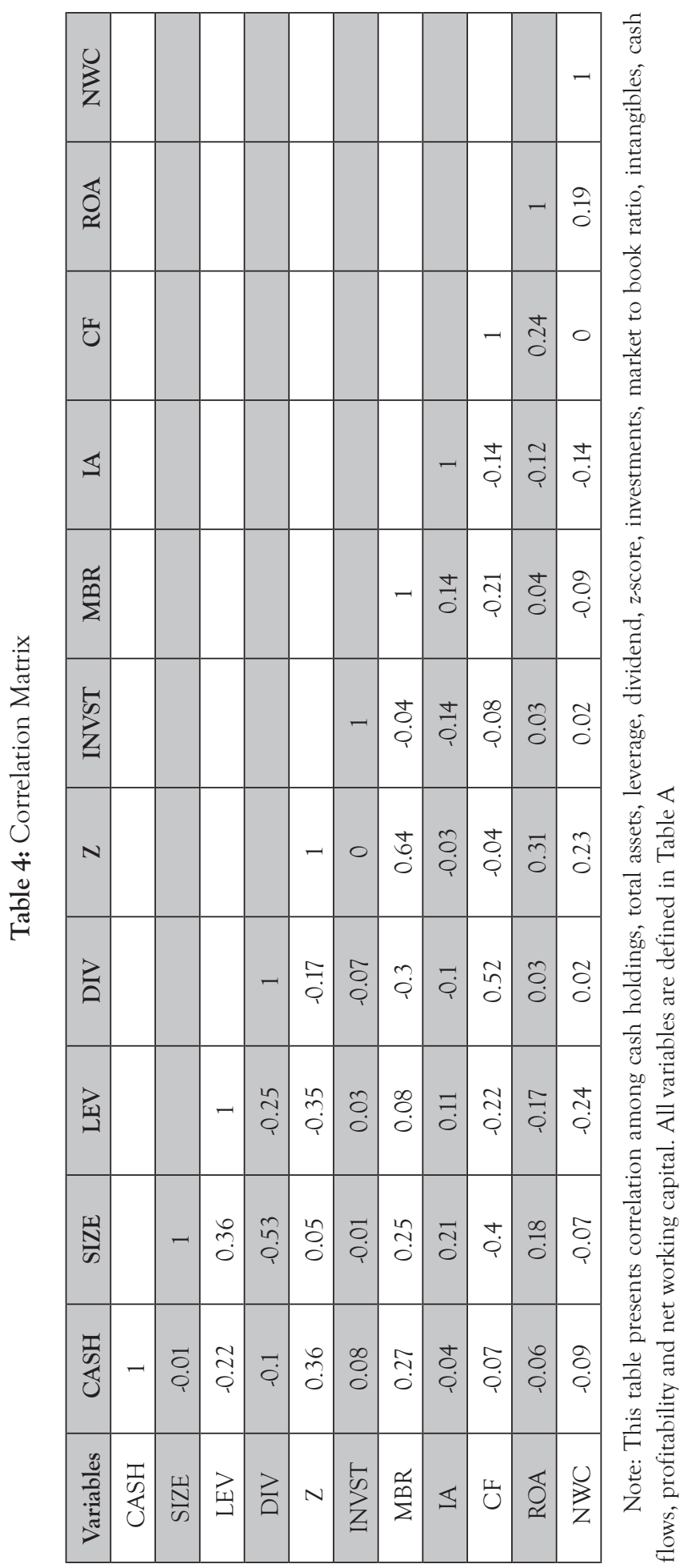


Table 5: Regression Results

\begin{tabular}{|c|c|c|c|c|c|c|c|}
\hline Variables & $\begin{array}{l}\text { World } \\
\text { sample }\end{array}$ & Africa & $\begin{array}{c}\text { Asia } \\
\text { Pacific }\end{array}$ & Europe & $\begin{array}{l}\text { Middle } \\
\text { East }\end{array}$ & $\begin{array}{c}\text { North } \\
\text { America }\end{array}$ & $\begin{array}{c}\text { South } \\
\text { America }\end{array}$ \\
\hline \multirow[t]{2}{*}{$\mathrm{C}$} & 0.058 & 0.042 & 0.054 & 0.141 & -0.016 & -0.04 & 0.052 \\
\hline & $(-20.11)$ & $(-2.39)$ & -14.54 & -9.04 & -0.21 & -1.9 & -2.26 \\
\hline \multirow[t]{2}{*}{ LNTA } & $0.008^{* * *}$ & $0.007^{* * *}$ & $0.008^{* * *}$ & $-0.004^{* *}$ & $0.024^{* * *}$ & $0.033^{* * *}$ & 0.003 \\
\hline & $(20.25)$ & $(2.51)$ & (17.70) & $(-2.06)$ & $(2.30)$ & (12.88) & $(0.90)$ \\
\hline \multirow[t]{2}{*}{ LEVDBT } & $-0.160^{* * *}$ & $-0.016^{* * *}$ & $-0.169^{* * *}$ & $-0.002^{*}$ & $-0.004^{* *}$ & $-0.118^{* * *}$ & $0.008^{* * *}$ \\
\hline & $(-37.91)$ & $(-3.46)$ & $(-29.45)$ & $(-1.79)$ & $(-2.21)$ & $(-13.44)$ & $(-2.34)$ \\
\hline \multirow[t]{2}{*}{ DIVTA } & $-0.003^{* * *}$ & $0.188^{* * *}$ & $-0.002^{* * *}$ & $0.104^{* * *}$ & $0.094^{*}$ & $0.288^{* * *}$ & $-0.237^{* * *}$ \\
\hline & $(-4.16)$ & $(2.45)$ & $(-2.50)$ & $(3.70)$ & (1.89) & $(6.41)$ & $(-3.85)$ \\
\hline \multirow[t]{2}{*}{ PV } & $0.001^{* * *}$ & $0.001^{* * *}$ & $0.001^{* * *}$ & $0.001^{* * *}$ & $0.002^{* * *}$ & $0.001^{* * *}$ & -0.001 \\
\hline & (21.66) & $(-2.36)$ & $(-15.88)$ & $(-3.94)$ & $(-2.66)$ & $(-6.22)$ & $(-0.58)$ \\
\hline \multirow[t]{2}{*}{ ZSCORE } & $0.019^{* * *}$ & $0.004^{* * *}$ & $0.022^{* * *}$ & $0.015^{* * *}$ & $0.018^{* * *}$ & $0.008^{* * *}$ & 0.002 \\
\hline & $(52.44)$ & $(1.72)$ & $(42.06)$ & $(22.80)$ & (5.17) & $(14.84)$ & (1.02) \\
\hline \multirow[t]{2}{*}{ CAPX } & $-0.008^{* * *}$ & $-0.019^{* * *}$ & $0.011^{* * *}$ & $-0.195^{* * *}$ & $-0.202^{* *}$ & $-0.507^{* * *}$ & $-0.190^{* * *}$ \\
\hline & $(-2.53)$ & $(-2.74)$ & $(2.80)$ & $(-8.15)$ & $(-1.98)$ & $(-15.09)$ & $(-4.16)$ \\
\hline \multirow[t]{2}{*}{ MBR } & $0.008^{* * *}$ & $-0.153^{* * *}$ & $-0.010^{* * *}$ & $-0.014^{* * *}$ & $-0.018^{*}$ & $-0.003^{* *}$ & $0.012^{* * *}$ \\
\hline & $(7.40)$ & $(-3.02)$ & $(-6.61)$ & $(-8.10)$ & $(-1.77)$ & $(-2.42)$ & (2.73) \\
\hline \multirow[t]{2}{*}{ GRW } & $-0.029^{* * *}$ & $-0.039^{* *}$ & $-0.018^{* * *}$ & $-0.061^{* * *}$ & $-0.264^{* * *}$ & $-0.125^{* * *}$ & $-0.0634^{* * *}$ \\
\hline & $(-12.67)$ & $(-2.01)$ & $(-5.58)$ & $(-14.56)$ & $(-9.05)$ & $(-29.45)$ & $(-4.55)$ \\
\hline \multirow[t]{2}{*}{$\mathrm{CF}$} & $0.045^{* * *}$ & $0.162^{* * *}$ & $0.047^{* * *}$ & $0.0607^{* * *}$ & $0.095^{*}$ & $0.057^{* * *}$ & $0.212^{* * *}$ \\
\hline & (12.86) & $(4.68)$ & (10.58) & (6.96) & (1.67) & $(4.54)$ & (8.31) \\
\hline \multirow[t]{2}{*}{$\mathrm{ROA}$} & $-0.129^{* * *}$ & $0.174^{* * *}$ & $-0.186^{* * *}$ & $0.035^{* * *}$ & -0.020 & -0.010 & $0.079^{* *}$ \\
\hline & $(-18.87)$ & $(3.37)$ & (17.18) & (3.14) & $(-0.36)$ & $(-1.14)$ & (2.16) \\
\hline \multirow[t]{2}{*}{ NWC } & $-0.139^{* * *}$ & $-0.216^{* * *}$ & $-0.121^{* * *}$ & $-0.219^{* * *}$ & $-0.288^{* * *}$ & $-0.291^{* * *}$ & $-0.099^{* * *}$ \\
\hline & $(-31.43)$ & $(-7.26)$ & $(-20.21)$ & $(-29.84)$ & $(-6.84)$ & $(-24.15)$ & $(-4.50)$ \\
\hline Adj. R Sq. & 0.438 & 0.707 & 0.218 & 0.796 & 0.755 & 0.828 & 0.174 \\
\hline $\begin{array}{l}\text { Prob. J } \\
\text { Stat. }\end{array}$ & 0.0013 & 0.0000 & 0.486 & 0.0000 & 0.0251 & 0.0000 & 0.0008 \\
\hline $\begin{array}{c}\text { Hausman } \\
\text { Signif. }\end{array}$ & 0.0000 & 0.0001 & 0.0000 & 0.0000 & 0.0000 & 0.0000 & 0.148 \\
\hline $\begin{array}{c}\text { Hausman. } \\
\text { Values }\end{array}$ & 712.631 & 36.631 & 45.907 & 159.268 & 52.876 & 724.150 & 15.817 \\
\hline
\end{tabular}

Note: The results of the regressions of cash holdings and its determinants are presented in this table. The sample period is 2007-2016 and 57,470 firm-years from 47 countries in six regions are included. Variable definitions are reported in Table 1. All financial variables have been winsorized at the 5\% level. Robust t-statistics at the firm level are presented in parentheses. Hauseman test reports value of Chi-Sq. Statistic and its significance for the world sample. ${ }^{*} \mathrm{P}<0.10 ;{ }^{* *} \mathrm{P}<0.05 ;{ }^{* *} \mathrm{P}<0.01$ 
factors that influence the cash holding decision of non-financial firms worldwide. The results are placed at Table 5. It states that size and cash holdings are positively related with each other which show that large firms have capacity to hoard more cash reserves. The results show that coefficient of size for world sample is 0.008 which means that one unit increase in size causes increase of $0.8 \%$ in cash holdings. The results are in accordance with Ozkan and Ozkan (2004) and Liu et al. (2015) but in contradiction with Lins et al. (2010) and Qiu and Wan (2015). Although, pecking order theory and trade off theory do not support result of this study, shareholders' protection hypothesis allows large firm to hold more cash as such firms protect shareholders' rights due to strict external monitoring. However, consistent with $\mathrm{H} 1$, we find that size has significant positive effect on cash holdings.

For the world sample, we find that leverage has significant negative effect on cash holdings. This result is in accordance with Acharya et al. (2008), Al- Najjar (2012), Chen et al. (2014) and Guizani (2017) who also find the same effect in their studies. Thus, such firms have to rely less on cash holdings to finance their investments as they have more ability to access external funds. As per pecking order theory, little cash holdings and high levels of debt occur simultaneously when firms' investments are more than retained earnings (Ferreira \&Vilela, 2004). Further, according to free cash flow hypothesis, capital markets monitor the firms more strictly and so managers are prevented to use cash at their discretion. Transaction cost motive supports that less cash holdings are associated with high levered firms because such firms bear higher costs on investment in liquid assets.

The results also show that dividend payments are negatively associated with cash holdings. Khieu and Pyles (2012) and Julio and Yook (2012) and Al-Najjar (2013) find negative relationship between the said variables. However, Chen et al. (2012) and Hill et al.(2014) find positive relationship in their studies. Although, signaling theory and shareholders' power hypothesis support that dividend payments are positively related with cash holdings, packing order theory and trade off theory predict that dividend payments are negatively associated with cash holdings. Nevertheless, our results support $\mathrm{H} 3$ which state that dividend is significantly and negatively related with cash holdings.

For the world sample, Z-score is positively related with cash holdings. The same relationship is also observed by Opler et al. (1999), Harford et al. (2008) and Subramaniam et al. (2011) in their studies. However, according to Lins et al. (2010) and Khieu and Pyles (2012), the influence of Altman Z-score on the corporate cash level cannot be determined unambiguously. Nevertheless, in our results, Z-score and cash holdings are significantly related with each other which confirm our hypothesis H4 that financial distress has significant positive/ negative effect on cash holdings. 
It is observed from the Table 5 that market to book value and intangibles are negatively associated with cash holdings. Khieu and Pyles (2012) and Bigelli and Vidal (2012) also find thatgrowthis negatively related with cash holdings but our results are in contradictory with Foley et al. (2007), Iskandar-Datta et al. (2014) and Chen et al. (2015) who find that growth has positive effect on cash reserves. The results of the analysis confirm our hypothesis $\mathrm{H} 5$ that growth has significant positive/ negative effect on cash holdings.

It is revealed from the Table 5 that investments have significant positive effect on cash holdings. The same results are presented by Opler et al (1999), Mikkelson and Partch (2003), Harford et al. (2008) and Huang et al. (2013). However, Dittmar et al. (2003) and Hoberg et al. (2014) report negative relationship for capital expenditures as well as Bates, Kahle, and Stulz (2009) and Oler and Picconi (2014) for acquisition expenditures. Also, our results are in contradiction with pecking order theory. Nevertheless, our results support the hypothesis H6 that investments have significant positive/ negative effect on cash holdings.

The results at Table 5 show that cash flows are significantly and positively related with cash reserves. The results are in accordance with pecking order theory and free cash flow hypothesis. Also, Kalcheva and Lins (2007), D’Mello, Krishnaswami, and Larkin (2008) and Weidemann (2016) find the same results in their studies. Duchin (2010) and Chen et al. (2012) find that cash flows have negative impact on cash holdings. However, our results support our hypothesis $\mathrm{H} 7$ that cash flows and cash holdings are significantly associated with each other. Table 5 shows that profitability is negatively related with cash holdings. The results are not only in contrast with Dittmar et al., (2003), Ferreira and Vilela (2004), Al-Najjar and Belghitar, (2011), and Al-Najjar and Clark (2016) but also do not support pecking order theory and hypothesis H8.

It is revealed form the Table 5 that net working capital is negatively associated with cash holdings for the our world sample. Almeida et al. (2004), Bates et al. (2009),Subramaniam et al. (2011), Al-Najjar, 2013 and Liu et al. (2014) find the same relationship in their studies. Our results are in accordance with trade off theory also and confirms hypothesis $\mathrm{H} 9$ which state that net working capital is negatively associated with cash holdings.

\subsubsection{Region wise regression results}

In this sub-section, regression results on different regions of the world including Africa, Asia Pacific, Europe, Middle East, North America and South America are presented. The results are presented at Table 5. The results show fixed effect for Asia Pacific, Europe, Africa, Middle East and North America and random effect for South 
America. The results of Hausman test are significant for Asia Pacific, Europe, Africa, Middle East and North America and insignificant for South America.

The results reported at Table 5 indicate effect of different cash holding determinants including total assets, leverage, dividend, Z-score, investment, mark to book ratio, intangibles, cash flows, profitability and net working capital on cash reserves in respect of different regions of the world.

It is revealed from Table 5 that size is significantly and positively associated with cash holdings for Africa, Asia Pacific, Middle East and North America and negative for Europe. The size is positively associated with cash holdings for South America but relationship is insignificant. The coefficients of size for Africa, Asia Pacific, Middle East and North America, Europe and South America are 0.007, 0.008, 0.024, 0.033, -0.004 and 0.003 respectively. Positive association between size and cash holdings in respect of four regions is in accordance with the result of whole world sample, shareholders' protection hypothesis and studies of Ozkan and Ozkan (2004) and Liu et al. (2015). Negative significant association of size with cash holdings for Europe is supported by pecking order theory, trade off theory and studies of Lins et al. (2010) and Qiu and Wan (2015).

Leverage is significantly and negatively associated with cash holdings for Africa, Asia Pacific, Europe, Middle East and North America and positively related with cash holdings for South America. The coefficients of leverage for Africa, Asia Pacific, Europe, Middle East, North America and South America are -0.016, -0.169, -0.002, - -0.004, -0.118 and 0.008 respectively. Leverage and cash holdings are negatively associated with each other in the world sample also. This negative relationship between the said variables is supported by pecking order theory, free cash flow hypothesis and studies of Acharya et al. (2008), Al- Najjar (2012), Chen et al. (2014) and Guizani (2017).

Dividend has significant positive effect on cash holdings for Africa, Europe, Middle East and North America. It is negatively associated with the cash reserves for Asia Pacific and South America. The coefficients of dividend for Africa, Asia Pacific, Europe, Middle East, North America and South America are 0.188, -0.002, 0.104, $0.097,0.288$ and -0.237 respectively. In the world sample, dividend and cash holdings are negatively associated. The reason why Asia Pacific dominates the results of world sample is the number of observation which is more than $56 \%$ for Asia Pacific. Further, negative association of dividend with cash holdings is as per pecking order theory, trade off theory and studies of Khieu and Pyles (2012), Julio and Yook (2012) and Al-Najjar (2013). Positive association of dividend with cash holdings for four regions is in line with signaling theory, shareholders' power hypothesis and studies of Chen et al. (2012) and Hill et al. (2014). 
Z-score is positively associated with cash holdings for all the regions under study, however, for South America relationship is insignificant. The coefficients of Z-score for Africa, Asia Pacific, Europe, Middle East, North America and South America are $0.004,0.022,0.015,0.018,0.008$ and 0.002 respectively. In the world sample also, Z-score has significant positive effect on cash holdings. The same result is found by Opler et al. (1999), Harford et al. (2008) and Subramaniam et al. (2011)

Investments are significantly and negatively associated with cash holdings for Africa, Europe, Middle East, North America and South America and have significant positive effect on cash reserves for Asia Pacific. The coefficients of investments for Africa, Asia Pacific, Europe, Middle East, North America and South America are $-0.019,0.010,-0.195,-0.202,-0.507,-0.190$ respectively In the world sample, investments are positively associated with cash holdings. This relationship is influenced by large number of observations of Asia Pacific region. The negative relationship between investments and cash holdings for five regions of the world is supported by pecking order theory and studies of Dittmar et al. (2003), Hoberg et al. (2014), Bates et al. (2009) and Oler and Picconi (2014). Opler et al (1999), Mikkelson and Partch (2003), Harford et al. (2008) and Huang et al. (2013) find investments have positive effect on cash holdings which is same as we identify in the case of Asia Pacific region.

Market to book ratio is significantly negatively associated with cash holdings in respect of Africa, Asia Pacific, Europe, Middle East, North America like world sample, whereas, the said ratio is positively related to cash reserves for South America. The coefficients of market to book ratio for Africa, Asia Pacific, Europe, Middle East, North America and South America are -0.153, -0.010, -0.014, - -0.018, - -0.003 and 0.012. Intangibles have significant negative relationship with cash holdings for all the regions like world sample. The coefficients of intangibles for Africa, Asia Pacific, Europe, Middle East, North America and South America are -0.039, -0.022, -0.061, -0.264, -0.125 and -0.063 respectively.

Cash flows have significant positive effect on cash holdings for all the regions and also for the world sample. The coefficients of cash flows for Africa, Asia Pacific, Europe, Middle East, North America and South America are 0.163, 0.047, 0.061, $0.096,0.057$ and 0.219 respectively. Net working capital has significant negative effect on cash holdings for all the regions as is the case of world sample. The coefficients of net working capital for Africa, Asia Pacific, Europe, Middle East, North America and South America are $-0.216,-0.120,-0.219,-0.288,-0.291$ and -0.099 respectively.

Profitability has significant positive effect on cash holdings for Africa, Europe and South America and has significant negative effect for Asia Pacific region. As stated above, pecking order theory predicts positive relationship between profitability and 
cash holdings. On the other hand, signaling theory suggests a positive association between profitability and dividends, since profitable firms are able to pay dividends (Jensen, 1986; Aivazian, Booth, and Cleary, 2003). Thus, as per signaling theory, amount of cash holdings may be reduced with the increase in profitability of the firm as need to hold cash reserves is reduced with the increase in profitability. The access to capital market for financing becomes easy with increase in profitability, thus lessening the need to hoard cash. The coefficients of profitability for Africa, Asia Pacific, Europe and South America are 0.174, -0.186, 0.035 and 0.079 respectively. The positive relationship between profitability and cash holdings for Africa, Europe and South America is in line with pecking order theory and negative relationship between profitability and cash holdings for Asia Pacific is as per signaling theory. The relationship between profitability and cash holdings turns to be insignificant for Middle East and North America, though negative. The effect of profitability on cash holdings for world sample is negative due to major representation of Asia pacific region. The positive association between profitability and cash holdings is in line with pecking order theory and studies of Dittmar et al., (2003), Najjar and Belghitar (2011) and Al-Najjar and Clark (2016).

To conclude, there are some variables including leverage, Z-score, MBR, intangibles, cash flows and net working capital which have similar significant relationships with cash holdings across the regions. Some exceptions are with South America where leverage and MBR have positive relationships with cash holdings whereas all other regions including world sample have negative relationship between the said variables. Also, Z-score is insignificant for South America whereas this variable is significant for all other regions. Nevertheless, the differences across the regions regarding signs of coefficients are due to formal and informal intuitions which do not only vary across the regions but also across the countries, though, same are not focus of this study.

\section{Conclusion}

This study investigates cash holdings in different regions of the world for the period from 2007 to 2016.The results indicate that for the regions under study, size, leverage, dividend, investments, market to book ratio, intangibles, Z-score, cash flows, profitability and net working capital have significant impact on cash holdings. Moreover, we identify regional differences and similarities in the effects of cash holding determinants. This differentiation helps identifying sources of variation in the general association between a determinant and the level of cash.

We identify impact of various determinants on cash holdings in two phases. In the first phase, overall effect of different variables on cash holdings is observed. We find that cash holdings are directly influenced by size, Z-score, investments and 
cash flows. Moreover, the corporate cash reserves decrease with increase in leverage, dividend, market to book ratio, intangibles, profitability and net working capital.

In the second phase, we investigate effect of different variables on cash holdings in different regions of the world. It is found that there are geographical differences on account of effect of cash holding determinants. This study shows that although cash holding determinants have similar effect in different regions of the world, some exceptions are also found in some regions. This difference is due to institutional frameworks which are different from one region to other. The countries under each region have different institution settings which have varying effect on the relationship between cash holding determinants and cash holdings. The literature states that formal institutions including shareholder rights, creditor rights, corporate governance and financial developments influence cash holding decision of the firms (La Porta, Silanes, Shleifer, \& Vishny, 2000; Dittmar et al., 2003; Hu and Kumar, 2004; Officer, 2011; Michaely and Roberts, 2012; Grullon and Michaely, 2014; John, Knyazeva and Knyazeva, 2015; Bhattacharya, Li and Rhee, 2016). Apart from formal institutions national culture of a country has also its impact on cash level of the firms operating in the country (Chang and Noorbakhsh, 2009; Chen et al., 2015).

This study analyzes cash holding determinants in six regions of the world. We expect that differences of impact of cash holding determinants are due to different institutions prevailed in the countries under each region. Weidmann (2016) shows that the geographic region and the firm-level of information asymmetries affect the association between the determinants and the level of cash. They find that cash determinants are similar in North America and Europe but different in Asia We also expect that differences in some of the cash holding determinants in different regions may be attributed to institutional differences whether formal or informal. The same is suggested for future research with reference to the regions under this study.

The results of this study are very important for researchers and the managers of corporations working in international scenarios as this is a comprehensive attempt to analyze cross region comparison of cash holding determinants. The results of this study may be used to understand application of different theories of cash holdings including trade off, packing order, FCF and shareholders' right hypothesis in different regions of the world.

The sample of companies in this study gives better understanding of the debate why firms hold cash. Further, importance of analyzing cash holding determinants is emphasized by investigating this debate in six regions of the world. Accordingly, our aim in this study is to find similarities and differences in different regions of the world with respect to factors influencing cash holding decision. The results of this 
study provide important underpinnings for taking strategic decision of cash holdings in international context.

\section{References}

Acharya, V. V., Almeida, H., \& Campello, M. (2007). Is cash negative debt? A hedging perspective on corporate financial policies. Journal of Financial Intermediation, 16(4), 515-554.

Aivazian, V., Booth, L., \& Cleary, S. (2003). Do emerging market firms follow different dividend policies from US firms? Journal of Financial research, 26(3), 371-387.

Akbar, M., Ali, S., \& Tariq, F. (2009). The determinants of capital structure in the textile sector of Pakistan. Business E Economic Review, 1(1), 15-19.

Almeida, H., Campello, M., \& Weisbach, M. S. (2004). The cash flow sensitivity of cash. The Journal of Finance, 59(4), 1777-1804.

Al-Najjar, B. (2013). The financial determinants of corporate cash holdings: Evidence from some emerging markets. International business review, 22(1), 77-88.

Al-Najjar, B., \& Clark, E. (2017). Corporate governance and cash holdings in MENA: Evidence from internal and external governance practices. Research in International Business and Finance, 39, 1-12

Al-Najjar, B., \& Belghitar, Y. (2011). Corporate cash holdings and dividend payments: Evidence from simultaneous analysis. Managerial and decision Economics, 32(4), 231-241.

Arellano, M. (2003). Panel data econometrics. Oxford university press.

Baltagi, B. (2008). Econometric analysis of panel data. John Wiley \& Sons.

Bates, T. W., Kahle, K. M., \& Stulz, R. M. (2009). Why do US firms hold so much more cash than they used to? The Journal of Finance, 64(5), 1985-2021.

Bhattacharya, D., Li, W. H., \& Rhee, S. G. (2016). Does better corporate governance encourage higher payout? risk, agency cost, and dividend policy. Available at https://hermes-ir.lib.hit-u.ac.jp/rs/bitstream/10086/27754/3/070_hiasDP-E-20.pdf

Bigelli, M., \& Sánchez-Vidal, J. (2012). Cash holdings in private firms. Journal of Banking E\& Finance, 36(1), 26-35.

Booth, L., Aivazian, V., Demirguc-Kunt, A., \&Maksimovic, V. (2001). Capital structures in developing countries. The Journal of Finance, 56(1), 87-130.

Chang, K., \& Noorbakhsh, A. (2009). Does national culture affect international corporate cash holdings? Journal of Multinational Financial Management, 19(5), 323-342.

Chen, Q., Chen, X., Schipper, K., Xu, Y., \& Xue, J. (2012). The sensitivity of corporate cash holdings to corporate governance. The Review of Financial Studies, 25(12), 3610-3644. 
Chen, Y., Dou, P. Y., Rhee, S. G., Truong, C., \& Veeraraghavan, M. (2015). National culture and corporate cash holdings around the world. Journal of Banking $\mathcal{E}$ Finance, 50, 1-18.

Crutchley, C. E., Jensen, M. R., Jahera Jr, J. S., \& Raymond, J. E. (1999). Agency problems and the simultaneity of financial decision making: The role of institutional ownership. International Review of Financial Analysis, 8(2), 177-197.

D’Mello, R., Krishnaswami, S., \& Larkin, P. J. (2008). Determinants of corporate cash holdings: Evidence from spin-offs. Journal of Banking $\mathcal{B}$ Finance, 32(7), 1209-1220.

Dittmar, A. K., \& Duchin, R. (2010). The dynamics of cash. Ross School of Business, Working Paper No. 1138

Dittmar, A., \& Mahrt-Smith, J. (2007). Corporate governance and the value of cash holdings. Journal of Financial Economics, 83(3), 599-634.

Dittmar, A., Mahrt-Smith, J., \& Servaes, H. (2003). International corporate governance and corporate cash holdings. Journal of Financial and Quantitative Analysis, 38(1), 111-133.

Dittmar, A., Mahrt-Smith, J., \& Servaes, H. (2003). International corporate governance and corporate cash holdings. Journal of Financial and Quantitative analysis, 38(1), 111-133.

Duchin, R. (2010). Cash holdings and corporate diversification. The Journal of Finance, 65(3), 955-992.

Faleye, O. (2004). Cash and corporate control. The Journal of Finance, 59(5), 2041-2060.

Ferreira, M. A., \& Vilela, A. S. (2004). Why do firms hold cash? Evidence from EMU countries. European Financial Management, 10(2), 295-319.

Floyd, E., Li, N., \& Skinner, D. J. (2015). Payout policy through the financial crisis: The growth of repurchases and the resilience of dividends. Journal of Financial Economics, 118(2), 299-316.

Foley, C. F., Hartzell, J. C., Titman, S., \&Twite, G. (2007). Why do firms hold so much cash? A tax-based explanation. Journal of Financial Economics, 86(3), 579-607.

Gao, H., Harford, J., \& Li, K. (2013). Determinants of corporate cash policy: Insights from private firms. Journal of Financial Economics, 109(3), 623-639.

García-Teruel, P. J., \& Martínez-Solano, P. (2008). On the determinants of SME cash holdings: Evidence from Spain. Journal of Business Finance $\mathcal{E}$ Accounting, 35(1-2), 127-149.

Grullon, G., \& Michaely, R. (2014). The impact of product market competition on firms' payout policy. Unpublished working paper, Rice University.

Guizani, M. (2017). The financial determinants of corporate cash holdings in an oil rich country: Evidence from Kingdom of Saudi Arabia. Borsa Istanbul Review, 17(3), 133-143.

Guney, Y., Ozkan, A., \& Ozkan, N. (2003). Additional international evidence on corporate cash holdings. Working Paper. 
Harford, J., Mansi, S. A., \& Maxwell, W. F. (2008). Corporate governance and firm cash holdings in the US. Journal of Financial Economics, 87, 535-555.

Hill, M. D., Fuller, K. P., Kelly, G. W., \& Washam, J. O. (2014). Corporate cash holdings and political connections. Review of Quantitative Finance and Accounting, 42(1), 123-142.

Hoberg, G., Phillips, G., \& Prabhala, N. (2014). Product market threats, payouts, and financial flexibility. The Journal of Finance, 69(1), 293-324.

Hu, A., \& Kumar, P. (2004). Managerial entrenchment and payout policy. Journal of Financial and Quantitative Analysis, 39(4), 759-790.

Huang, J., \& Kisgen, D. J. (2013). Gender and corporate finance: Are male executives overconfident relative to female executives? Journal of Financial Economics, 108(3), 822-839.

Iskandar-Datta, M. E., \& Jia, Y. (2014). Investor protection and corporate cash holdings around the world: New evidence. Review of Quantitative Finance and Accounting, 43(2), 245-273.

Jensen, M. C. (1986). Agency costs of free cash flow, corporate finance, and takeovers. The American economic review, 76(2), 323-329.

Jensen, M. C., \& Meckling, W. H. (1976). Theory of the firm: Managerial behavior, agency costs and ownership structure. Journal of Financial Economics, 3(4), 305-360.

John, K., Knyazeva, A., \& Knyazeva, D. (2015). Governance and payout pre-commitment. Journal of Corporate Finance, 33, 101-117.

Julio, B., \& Yook, Y. (2012). Political uncertainty and corporate investment cycles. The Journal of Finance, 67(1), 45-83.

Kalcheva, I., \& Lins, K. V. (2007). International evidence on cash holdings and expected managerial agency problems. The Review of Financial Studies, 20(4), 1087-1112.

Kato, K., Li, M., \& Skinner, D. J. (2017). Is Japan Really a "Buy"? The Corporate Governance, Cash Holdings and Economic Performance of Japanese Companies. Journal of Business Finance $\mathcal{E}$ Accounting, 44(3-4), 480-523.

Khieu, H. D., \& Pyles, M. K. (2012). The influence of a credit rating change on corporate cash holdings and their marginal value. Financial Review, 47(2), 351-373.

Kinoshita, Y., \& Campos, N. F. (2008). Foreign direct investment and structural reforms: Evidence from Eastern Europe and Latin America (No. 3332). International Monetary Fund.

La Porta, R., Lopez-de-Silanes, F., Shleifer, A., \& Vishny, R. (2000). Investor protection and corporate governance. Journal of Financial Economics, 58(1), 3-27.

Lin, C., Officer, M. S., \& Zou, H. (2011). Directors' and officers' liability insurance and acquisition outcomes. Journal of Financial Economics, 102(3), 507-525. 
Lins, K. V., Servaes, H., \& Tufano, P. (2010). What drives corporate liquidity? An international survey of cash holdings and lines of credit. Journal of Financial Economics, 98(1), 160-176.

Liu, Y., Mauer, D. C., \& Zhang, Y. (2014). Firm cash holdings and CEO inside debt. Journal of Banking EB Finance, 42, 83-100.

Martínez-Sola, C., García-Teruel, P. J., \& Martínez-Solano, P. (2013). Corporate cash holding and firm value. Applied Economics, 45(2), 161-170.

Michaely, R., \& Roberts, M. R. (2012). Corporate dividend policies: Lessons from private firms. The Review of Financial Studies, 25, 711-746.

Mikkelson, W. H., \& Partch, M. M. (2003). Do persistent large cash reserves hinder performance? Journal of Financial and Quantitative Analysis, 38(2), 275-294.

Miller, M. H., \& Orr, D. (1966). A model of the demand for money by firms. The Quarterly Journal of Economics, 80(3), 413-435.

Myers, S. C. (1984). The capital structure puzzle. The Journal of Finance, 39(3), 574-592.

Myers, S. C., \& Majluf, N. S. (1984). Corporate financing and investment decisions when firms have information that investors do not have. Journal of Financial Economics, 13(2), 187-221.

Oler, D. K., \& Picconi, M. P. (2014). Implications of insufficient and excess cash for future performance. Contemporary Accounting Research, 31(1), 253-283.

Opler, T., Pinkowitz, L., Stulz, R., \& Williamson, R. (1999). The determinants and implications of corporate cash holdings. Journal of Financial Economics, 52(1), 3-46.

Ozkan, A., \& Ozkan, N. (2004). Corporate cash holdings: An empirical investigation of UK companies. Journal of Banking $\mathcal{E}$ Finance, 28(9), 2103-2134.

Pinkowitz, L., Stulz, R. M., \& Williamson, R. (2015). Do US firms hold more cash than foreign firms do? The Review of Financial Studies, 29(2), 309-348.

Pinkowitz, L., Stulz, R., \& Williamson, R. (2006). Does the contribution of corporate cash holdings and dividends to firm value depend on governance? A cross\country analysis. The Journal of Finance, 61(6), 2725-2751.

Qiu, J., \& Wan, C. (2015). Technology spillovers and corporate cash holdings. Journal of Financial Economics, 115(3), 558-573.

Ramirez, A., \& Tadesse, S. (2009). Corporate cash holdings, uncertainty avoidance, and the multinationality of firms. International Business Review, 18(4), 387-403.

Roodman, D. (2009). How to do xtabond2: An introduction to difference and system GMM in Stata. Stata Journal, 9(1), 86-136.

Shao, L., Kwok, C. C., \& Guedhami, O. (2010). National culture and dividend policy. Journal of Inter- 
national Business Studies, 41(8), 1391-1414.

Stiglitz, J. E. (1974). On the irrelevance of corporate financial policy. The American Economic Review, 64(6), $851-866$.

Subramaniam, V., Tang, T. T., Yue, H., \& Zhou, X. (2011). Firm structure and corporate cash holdings. Journal of Corporate Finance, 17(3), 759-773.

Tong, Z. (2011). Firm diversification and the value of corporate cash holdings. Journal of Corporate Finance, 17(3), 741-758.

Verbeek, M. (2008). A guide to modern econometrics. John Wiley \& Sons.

Wang, M. (2015). Corporate cash holdings and adjustment behaviour in Chinese firms: An empirical analysis using generalized method of moments. Australasian Accounting Business $\mathcal{E}$ Finance Journal, 9(4), 20-37.

Weidemann, J. F. (2016). The determinants of cash holdings: Evidence from meta-regression analysis. Available at http://www.efmaefm.org/OEFMAMEETINGS/EFMA\%20ANNUAL\%20MEETINGS/2016-Switzerland/papers/EFMA2016_0120_fullpaper.pdf 
